\title{
Post Merger Financial Performance of Tata Motors Limited: An Evaluation
}

Jigna Chandrakant Trivedi*

National Institute of Cooperative Management, Gandhinagar, Gujarat, India;

jigna2804@gmail.com

\begin{abstract}
Mergers and Acquisitions (M\&A) are considered as quickest routes to expansion. M\&A is a prudent decision when compared to laying a green field project, which involves longer gestation period and huge investments. Companies are attracted to M\&A for availing economies of scale, economies of scope, enormous size and expansion of domestic and foreign markets. Rise in the disposable income of customers, has converted an all time luxury into a necessity. Indian automobiles market is an eyewitness to such a growing necessity. Indian companies are inclined to M\&A to reduce competition and grab larger market share. Automobile majors often try to bond with foreign players especially for new technology and tapping the new market in home country as well as cross border countries. Present study tries to analyze the motive of Tata Motors Limited for acquiring foreign brands and also tries to study the post merger financial performance of the company.
\end{abstract}

Keywords: Merger and Acquisitions, Profitability Ratios, Synergistic Benefits

\section{Introduction}

Companies tend to favour M\&A for availing market expansion, financial strength, general gains, own developmental plans, strategic purpose, corporate friendliness, desired level of integration, procurement of supplies, brand building and revamping of production facilities. Post liberalization policy has made the entry of stylish and eye-catching cars in India. Companies are in the all time race to upgrade the cars, technologically and bodily. India's passenger car and commercial vehicle manufacturing industry is the sixth largest in the world, with an annual production of more than 3.9 million units in 2011 [1]. Automobile sector mainly comprises passenger vehicles, commercial vehicles, three wheelers and two wheelers. Passenger vehicles consist of passenger cars, utility vehicles and multi-purpose vehicles [1]. Tata Motors Limited is India's largest automobile company, with consolidated revenues of Rs.1,65,654 crores (USD 32.5 billion) in 2011-12 [2]. It is the leader in commercial vehicles in each segment, and among the top three in passenger vehicles with winning products in the compact, midsize car and utility vehicle segments [2]. After the acquisition of foreign brands, Tata Motors has emerged as an international automobile company. Jaguar and Land Rover (JLR), was a business composed of the two iconic British brands which was acquired in 2008 [2]. Tata Motors acquired the two brands for US $\$ 2.3$ billion [3]. Present study is an attempt to analyze the motive of Tata Motors Limited for acquiring foreign brands and also tries to study the post merger financial performance of the company.

\section{Research Objective}

1. To understand the benefits derived by Tata Motors Ltd. in the post M\&A.

2. To comprehend the significance of 23 parameters involved in evaluating the financial performance such as: Profit Before Depreciation, Interest and Tax (PBDIT); Profit Before Tax (PBT); Profit after tax (PAT); Equity Dividend; Net Worth; Capital Employed; Return on Net-Worth (RONW); Return on Capital Employed (ROCE); Quick Ratio; Current Ratio; Interest Coverage Ratio; Earning per share (EPS); Dividend Per Share (DPS); Debt-Equity Ratio; Operation Margin Ratio; Gross Profit Margin Ratio; Cash-Profit Margin Ratio; Total Debt to Owner's

*Author for correspondence 
Fund Ratio; Debtors Turnover Ratio (Debtors T/o); Inventory Turnover Ratio (Inventory T/o); Fixed Assets Turnover Ratio (Fixed Assets T/o), Total Assets Turnover Ratio (Total Assets T/o) and Economic Value Added (EVA).

\section{Research Methodology}

In order to accomplish the mentioned objectives, descriptive research design was adopted to evaluate the post M\&A financial performance. Unrestricted non-probability based judgemental sampling was adopted for the study. Sampling element consisted of Indian automobile companies which had undergone M\&A in the time slot of 2006-2011. Sampling unit comprised of the top automobile company (Tata Motors Limited) listed on BSE which had undergone M\&A. The reason for selecting Tata Motors Limited for research was that the Tata group is well known for acquiring the higher value firms like Daweoo Commercial vehicle, Korea and Hispano Carrocera SA, Spain. This provides a room for discussion that whether the recent acquisition of Jaguar and Land Rover brands was fruitful M\&A or not.
The secondary data was collected from various sources like newspaper, magazines, books, periodicals etc. Websites especially of Bombay Stock Exchange (BSE), money control, Center for Monitoring Indian Economy (CMIE), business beacon were referred to for gathering data. Data was also retrieved from Ace Analyzer and Capitaline databases. Data was managed through Statistical Package for Social Sciences (SPSS 17) and Microsoft Excel 2003. Inferential statistics like repeated measure t-test was applied for analysis. The major limitation of the study was that Tata Motor's past M\&A deals could have been cross compared with the recent one. More than 23 financial parameters could have been used in the study.

\subsection{Synergies Expected from the Deal}

Tata Motors received many synergistic benefits on acquisition of JLR. Acquiring JLR provided significant potential for revenue synergies, including giving Tata greater international distribution, broader product range and better customer service skills. Tata gained access to world-class engineering capability. The deal had strengthened relationship between Tata's steel and motoring businesses [4].

Table 1. Test statistics for repeated measure T-test

\begin{tabular}{|c|c|c|c|}
\hline $\begin{array}{l}\text { Pre-Post } \\
\text { Financial Parameter }\end{array}$ & p-value & Decision & Result of M\&A \\
\hline PBDIT & 0.30 & $\mathrm{H}_{0}$ cannot be rejected & No significant Difference \\
\hline PAT & 0.63 & $\mathrm{H}_{0}$ cannot be rejected & No significant Difference \\
\hline Equity Dividend & 0.41 & $\mathrm{H}_{0}$ cannot be rejected & No significant Difference \\
\hline Return on Net-worth & 0.01 & $\mathrm{H}_{0}$ is rejected & Significant difference \\
\hline Return on Capital Employed & 0.05 & $\mathrm{H}_{0}$ is rejected & Significant difference \\
\hline Quick Ratio & 0.09 & $\mathrm{H}_{0}$ cannot be rejected & No significant Difference \\
\hline Current Ratio & 0.12 & $\mathrm{H}_{0}$ cannot be rejected & No significant Difference \\
\hline Interest Coverage Ratio & 0.01 & $\mathrm{H}_{0}$ is rejected & Significant difference \\
\hline Operating Margin Ratio & 0.61 & $\mathrm{H}_{0}$ cannot be rejected & No significant Difference \\
\hline Gross Profit Margin Ratio & 0.42 & $\mathrm{H}_{0}$ cannot be rejected & No significant Difference \\
\hline Cash Profit Margin Ratio & 0.61 & $\mathrm{H}_{0}$ cannot be rejected & No significant Difference \\
\hline Total Debt to Owners Fund Ratio & 0.18 & $\mathrm{H}_{0}$ cannot be rejected & No significant Difference \\
\hline Debtors T/o Ratio & 0.06 & $\mathrm{H}_{0}$ cannot be rejected & No significant Difference \\
\hline Inventory T/o Ratio & 0.72 & $\mathrm{H}_{0}$ cannot be rejected & No significant Difference \\
\hline Fixed Assets T/o Ratio & 0.06 & $\mathrm{H}_{0}$ cannot be rejected & No significant Difference \\
\hline Total Assets T/o Ratio & 0.03 & $\mathrm{H}_{0}$ is rejected & Significant difference \\
\hline EVA & 0.41 & $\mathrm{H}_{0}$ cannot be rejected & No significant Difference \\
\hline
\end{tabular}

Source: SPSS output based on compiled secondary data 
Tata Motors developed the strength in technological and product development, innovation capabilities to address the changing market trends. Company got the benefit of sharing best practices in manufacturing and quality assurance systems and processes. It also received enhanced human capital and managerial talent along with potential operational synergies. Acquiring JLR assisted the company to expand and diversify the international sales market, allowing it to reduce excessive reliance on Indian market. It helped to broaden the existing product portfolio of utility vehicles and sports utility vehicles and cross offerings.

\subsection{Post M\&A Evaluation of Financial Parameters of the Deal}

In order to compare the statistical significance of financial parameter pre and post M\&A deal, repeated measure $\mathrm{T}$-Test was applied. The hypothesis for applying T-test is as follows.

$H_{0}$ 1: The performance of Tata Motors Limited does not significantly differ before and after acquiring international automobile brands.
$H_{1}$ : The performance of Tata Motors Limited significantly differs before and after acquiring international automobile brands.

As mentioned in Table 1 of test statistics for repeated measure T-test, at 95\% level of confidence it may be inferred that for the financial parameters where the $\mathrm{p}$-value $<0.05, \mathrm{H}_{0}$ is rejected and $\mathrm{H}_{1}$ is accepted, i.e. The performance of Tata Motors Limited significantly differs before and after acquiring international automobile brands. It can be further observed that where the $\mathrm{p}$-value $>0.05, \mathrm{H}_{0}$ is not rejected, i.e. the performance of Tata Motors Limited do not significantly differ before and after acquiring international automobile brands.

\section{Findings and Conclusion}

From Table 2 it can be observed that overall analysis of financial parameters is done for Tata Motors Limited post M\&A. Interpretation of ratio and its implication is discussed in the table. It can be concluded that by acquiring Jaguar brand, Tata has entered the premium product segment especially the luxury performance car segment. Acquisition of Land Rover has enabled the company to

Table 2. Analysis of financial parameters

\begin{tabular}{|c|c|c|c|}
\hline $\begin{array}{l}\text { Post M\&A } \\
\text { Statistical Significance } \\
\text { of Financial Parameter }\end{array}$ & $\begin{array}{c}\text { \% Change } \\
\text { after } \\
\text { M\&A }\end{array}$ & Interpretation [5] & Implication \\
\hline PBDIT (Not Significant) & 18.84 & $\begin{array}{l}\text { PBDIT evaluates profitability } \\
\text { and not the cash flow. }\end{array}$ & $\begin{array}{l}\text { Post M\&A the absolute performance of } \\
\text { company has improved marginally. }\end{array}$ \\
\hline PBT (Not Significant) & $-22.27 \%$ & $\begin{array}{l}\text { PBT signals changes in } \\
\text { company's profit from } \\
\text { year to year basis. }\end{array}$ & $\begin{array}{l}\text { It indicates that company's absolute } \\
\text { performance has not significantly } \\
\text { decreased after M\&A. This marginal } \\
\text { decrease is due to high depreciation and } \\
\text { interest expenses after M\&A. }\end{array}$ \\
\hline PAT (Not Significant) & $-11.86 \%$ & $\begin{array}{l}\text { PAT represents the profit } \\
\text { available for distribution after the } \\
\text { discharge of all interest, expenses etc. }\end{array}$ & $\begin{array}{l}\text { It indicates that company's absolute } \\
\text { performance has significantly not } \\
\text { decreased after M\&A. This marginal } \\
\text { decrease is due to high tax expenses } \\
\text { after M\&A. }\end{array}$ \\
\hline $\begin{array}{l}\text { Equity Dividend } \\
\text { (Not Significant) }\end{array}$ & $27.00 \%$ & $\begin{array}{l}\text { Equity Dividend indicates company's } \\
\text { earnings retention policy and profit } \\
\text { distribution to equity share holders. }\end{array}$ & $\begin{array}{l}\text { It indicates that company's absolute } \\
\text { equity dividend policy has significantly } \\
\text { not improved after M\&A due to } \\
\text { financing of the deal. }\end{array}$ \\
\hline Net-Worth (Significant) & $130.92 \%$ & $\begin{array}{l}\text { Net Worth is indicator of company's } \\
\text { total assets minus liabilities. }\end{array}$ & $\begin{array}{l}\text { Acquiring company's assets have } \\
\text { increased after M\&A and its worth has } \\
\text { considerably improved. }\end{array}$ \\
\hline $\begin{array}{l}\text { Capital Employed } \\
\text { (Significant) }\end{array}$ & $429.39 \%$ & $\begin{array}{l}\text { Capital Employed highlights the } \\
\text { investment required to function. It } \\
\text { indicates companies total assets less its } \\
\text { current liabilities. }\end{array}$ & $\begin{array}{l}\text { After M\&A bidder company's capital } \\
\text { employed has increased, which } \\
\text { represents that company has deployed } \\
\text { huge funds in connotation to its expansion }\end{array}$ \\
\hline
\end{tabular}


Table 2. (Continued)

\begin{tabular}{|c|c|c|c|}
\hline $\begin{array}{l}\text { Post M\&A } \\
\text { Statistical Significance } \\
\text { of Financial Parameter }\end{array}$ & $\begin{array}{c}\text { \% Change } \\
\text { after } \\
\text { M\&A }\end{array}$ & Interpretation [5] & Implication \\
\hline $\begin{array}{l}\text { Return on Net-worth } \\
\text { (Significant) }\end{array}$ & $-61.98 \%$ & $\begin{array}{l}\text { Return on Net Worth measures a } \\
\text { corporation's profitability by revealing } \\
\text { how much profit a company generates } \\
\text { with the money shareholders have } \\
\text { invested. }\end{array}$ & $\begin{array}{l}\text { It indicates decline in company's } \\
\text { performance after M\&A because increase } \\
\text { in new borrowings in terms of new equity } \\
\text { or debt and this may lead to initial decrease } \\
\text { in return on net worth, after M\&A. }\end{array}$ \\
\hline $\begin{array}{l}\text { Return on Capital } \\
\text { Employed (Significant) }\end{array}$ & $-62.62 \%$ & $\begin{array}{l}\text { This ratio indicates the efficiency } \\
\text { and profitability of a company's } \\
\text { capital investments. }\end{array}$ & $\begin{array}{l}\text { It indicates decline in company's } \\
\text { performance after M\&A because of } \\
\text { increase in new borrowings. }\end{array}$ \\
\hline $\begin{array}{l}\text { Quick Ratio } \\
\text { (Not Significant) }\end{array}$ & $-38.10 \%$ & $\begin{array}{l}\text { The quick ratio measures a company's } \\
\text { ability to meet its short-term } \\
\text { obligations with its most liquid } \\
\text { assets. }\end{array}$ & $\begin{array}{l}\text { It indicates company's position to pay its. } \\
\text { current liability. Company's quick ratio has } \\
\text { decreased which shows that after M\&A } \\
\text { company may not have enough liquid } \\
\text { assets to pay its short term obligations }\end{array}$ \\
\hline $\begin{array}{l}\text { Current Ratio } \\
\text { (Not Significant) }\end{array}$ & $-44.05 \%$ & $\begin{array}{l}\text { Current ratio checks if the short term } \\
\text { assets are readily available to pay off } \\
\text { its short term liabilities. }\end{array}$ & $\begin{array}{l}\text { Current ratio after M\&A has dropped } \\
\text { which indicates that company may face } \\
\text { problem in paying off its current liabilities. }\end{array}$ \\
\hline $\begin{array}{l}\text { Interest Coverage } \\
\text { Ratio (Significant) }\end{array}$ & $-63.48 \%$ & $\begin{array}{l}\text { Interest Coverage Ratio used to } \\
\text { determine how easily a company can } \\
\text { pay interest on outstanding debt. } \\
\text { The lower the ratio, the more the } \\
\text { company is burdened by debt expense. }\end{array}$ & $\begin{array}{l}\text { It indicates that the company's ability to } \\
\text { pay fixed charge obligations has decreased } \\
\text { significantly due to increase in borrowings } \\
\text { after M\&A. Although this decline would } \\
\text { remain for initial years only. }\end{array}$ \\
\hline EPS (Significant) & $-40.63 \%$ & $\begin{array}{l}\text { EPS is expressed as the ratio of the } \\
\text { net annual earnings of a company } \\
\text { to the number of shares outstanding. }\end{array}$ & $\begin{array}{l}\text { As number of share holders has increased } \\
\text { because of M\&A, the EPS of the company } \\
\text { has decreased. But however this decline } \\
\text { would be for a short period, because after } \\
\text { the realization of synergistic benefits } \\
\text { company's profitability will improve } \\
\text { considerably. Currently the high interest } \\
\text { cost also upsets the profit. }\end{array}$ \\
\hline DPS (Not Significant) & $-14.97 \%$ & $\begin{array}{l}\text { DPS is expressed as the ratio of the } \\
\text { equity dividend of a company to } \\
\text { the number of shares outstanding. }\end{array}$ & $\begin{array}{l}\text { DPS of companies has not decreased } \\
\text { significantly. Number of share holders has } \\
\text { increased because of M\&A. }\end{array}$ \\
\hline $\begin{array}{l}\text { Debt-Equity Ratio } \\
\text { (Not Significant) }\end{array}$ & $55.56 \%$ & $\begin{array}{l}\text { Debt Equity Ratio indicates what } \\
\text { proportion of equity and debt the } \\
\text { company is using to finance its assets. }\end{array}$ & $\begin{array}{l}\text { Company's debt-equity ratio is positive } \\
\text { after M\&A, which is a good sign for the } \\
\text { company. }\end{array}$ \\
\hline $\begin{array}{l}\text { Operating Margin Ratio } \\
\text { (Not Significant) }\end{array}$ & $-11.66 \%$ & $\begin{array}{l}\text { A ratio of operating margin calculated } \\
\text { as net income divided by revenues, or } \\
\text { net profits divided by sales. It measures } \\
\text { how much out of every rupee of sales a } \\
\text { company actually keeps in earnings. }\end{array}$ & $\begin{array}{l}\text { It indicates that the company's operating } \\
\text { efficiency has not decreased significantly. } \\
\text { But however this decline can be made } \\
\text { good after the economies of scale starts } \\
\text { accruing to the company. }\end{array}$ \\
\hline $\begin{array}{l}\text { Gross Profit Margin } \\
\text { Ratio (Not Significant) }\end{array}$ & $-26.95 \%$ & $\begin{array}{l}\text { The gross margin represents the percent } \\
\text { of total sales revenue that the company } \\
\text { retains after incurring the direct costs } \\
\text { associated with producing the goods } \\
\text { and services sold by a company. }\end{array}$ & $\begin{array}{l}\text { It indicates that the company's GP ratio has } \\
\text { decreased after M\&A but it is statistically } \\
\text { not significant. The marginal decrease will } \\
\text { be made good in forthcoming years. }\end{array}$ \\
\hline $\begin{array}{l}\text { Cash Profit Margin } \\
\text { Ratio (Not Significant) }\end{array}$ & $-11.66 \%$ & $\begin{array}{l}\text { The cash profit margin is the sale } \\
\text { price minus the cost of production } \\
\text { and associated costs such as distribution } \\
\text { and advertising. }\end{array}$ & $\begin{array}{l}\text { It indicates that the company's cash profit } \\
\text { has marginally decreased, but it is } \\
\text { statistically not significant. }\end{array}$ \\
\hline
\end{tabular}


Table 2. (Continued)

\begin{tabular}{|c|c|c|c|}
\hline $\begin{array}{l}\text { Post M\&A } \\
\text { Statistical Significance } \\
\text { of Financial Parameter }\end{array}$ & $\begin{array}{l}\text { \% Change } \\
\text { after } \\
\text { M\&A }\end{array}$ & Interpretation [5] & Implication \\
\hline $\begin{array}{l}\text { Total Debt to Owners } \\
\text { Fund Ratio (Not Significant) }\end{array}$ & $55.56 \%$ & $\begin{array}{l}\text { It gives users an idea of a company's } \\
\text { financial structure, or how it is financing } \\
\text { its operations, along with some insight } \\
\text { into its financial strength. The higher the } \\
\text { debt-to-capital ratio, the more debt the } \\
\text { company has when compared to its equity. }\end{array}$ & $\begin{array}{l}\text { Bidder company has raised debt to acquire } \\
\text { the target, therefore its debt equity ratio } \\
\text { has increased. }\end{array}$ \\
\hline $\begin{array}{l}\text { Debtors T/o Ratio } \\
\text { (Not Significant) }\end{array}$ & $-38.45 \%$ & $\begin{array}{l}\text { Debtors T/o ratio is used to quantify a } \\
\text { firm's effectiveness in extending credit } \\
\text { as well as collecting debts. }\end{array}$ & $\begin{array}{l}\text { It indicates that the company operates } \\
\text { on a cash basis or that its extension of } \\
\text { credit and collection of accounts receivable } \\
\text { is efficient. Post M\&A, the ratio has } \\
\text { decreased, but it is not statistically } \\
\text { significant. }\end{array}$ \\
\hline $\begin{array}{l}\text { Inventory T/o Ratio } \\
\text { (Not Significant) }\end{array}$ & $1.42 \%$ & $\begin{array}{l}\text { Inventory T/o ratio shows how many. } \\
\text { times a company's inventory is sold and } \\
\text { replaced over a period. }\end{array}$ & $\begin{array}{l}\text { It shows that inventory } \mathrm{t} / \mathrm{o} \text { post } \mathrm{M} \& \mathrm{~A} \text { has } \\
\text { improved, marginally }\end{array}$ \\
\hline $\begin{array}{l}\text { Fixed Assets T/o Ratio } \\
\text { (Not Significant) }\end{array}$ & $-27.17 \%$ & $\begin{array}{l}\text { It is a financial ratio of net sales to fixed } \\
\text { assets which measures a company's ability } \\
\text { to generate net sales from fixed-asset } \\
\text { investments - specifically property, } \\
\text { plant and equipment - net of depreciation. }\end{array}$ & $\begin{array}{l}\text { It indicates that the company's } \\
\text { effectiveness of using its investment in } \\
\text { fixed assets has not significantly decreased } \\
\text { after M\&A. }\end{array}$ \\
\hline $\begin{array}{l}\text { Total Assets T/o } \\
\text { Ratio (Significant) }\end{array}$ & $-49.78 \%$ & $\begin{array}{l}\text { Total Assets T/o ratio measures a firm's } \\
\text { efficiency at using its assets in generating } \\
\text { sales or revenue - the higher the number } \\
\text { the better it is. }\end{array}$ & $\begin{array}{l}\text { It indicates that the firm's efficiency of } \\
\text { using its assets in generating sales or } \\
\text { revenue has decreased. But the decline is } \\
\text { statistically significant. }\end{array}$ \\
\hline EVA (Not Significant) & $11.42 \%$ & $\begin{array}{l}\text { EVA is a measure of a company's } \\
\text { financial performance based on the } \\
\text { residual wealth calculated by deducting } \\
\text { cost of capital from its operating profit. } \\
\text { It added attempts to capture the true } \\
\text { economic profit of a company. }\end{array}$ & $\begin{array}{l}\text { EVA of the company has improved } \\
\text { marginally after M\&A. This improvement } \\
\text { shows high operating efficiency after } \\
\text { M\&A. }\end{array}$ \\
\hline
\end{tabular}

Source: Compiled from secondary data

broaden its portfolio. It can be deduced that Tata now has presence in the segments of cars viz., economy car or people's car (Nano) and luxury car (Jaguar).

\section{References}

1. Wikipedia. Automotive Industry in India. [Online]. Available: http://en.wikipedia.org/wiki/Automotive_industry_in_India

2. Tata Motors, Company Profile. [Online]. Available: http:// www.tatamotors.com/know-us/company-profile.php
3. Bajaj V., Business-Companies: Jaguar turns the corner with Tata, The Hindu, 2012. Available: http: //www.thehindu.com/ business / companies/article3851201.ece

4. Tutor2u., Business Studies. 6 Essential M\&A Cases: Tata Group Buys Jaguar Land Rover. Available: http:// www.Tutor 2 u.net/blog/index.php/business-studies/ comments/6-essential-ma-cases-tata-group-buys-jaguarland-rover

5. Investopedia,Dictionary.Available:http://www.investopedia. com/dictionary/\#axzz2C4nueNan 